\title{
Why Are Revisionist States Revisionist? Reviving Classical Realism as an Approach to Understanding International Change
}

\author{
Sten Rynning ${ }^{\mathrm{a}}$ and Jens Ringsmose ${ }^{\mathrm{b}}$ \\ ${ }^{a}$ Department of Political Science, University of Southern Denmark, Campusvej 55, Odense 5230, \\ Denmark. \\ E-mail: sry@sam.sdu.dk \\ ${ }^{\mathrm{b}}$ Danish Institute for Military Studies, Ryvangs Allé 1, Copenhagen 2100, Denmark. \\ E-mail: jer@difms.dk
}

In this article, we argue that Realism recently has eschewed big and important questions of war and peace and that revived Classical Realism can help bring Realism back on track. Modern Realists tend to assume that states are either all status quo players or all revisionists, and the result is a slippery grasp of the sources and dynamics of international change. To revive Classical Realism, we examine three dominant sets of criticism. We notably return to the classical texts of Realism to show that the classics were in fact not reductionist: they did not reduce either systemic or national phenomena (third and second image theory) to human nature (first image). Classical Realists understood the many intricate and delicate connections between these levels, and it is modern era Realists who are reductionists because they reduce explanations to systemic phenomena. We show how Classical Realism can respond in strength to its critics and ask the kind of research questions that again will advance our understanding of international change.

International Politics (2008) 45, 19-39. doi:10.1057/palgrave.ip.8800217

Keywords: Classical Realism; structural realism; revisionism and the status quo; international change; war and peace

\section{Introduction}

The solidity of the international status quo and concomitantly the strength of revisionism is a major concern to the theory of Realism because it purports to account for big questions of war and peace. ${ }^{1}$ By logical implication, the location, timing, and strength of challenges to the current world order should be a central issue to all Realists. It is odd, therefore, to observe that many contemporary Realists eschew these big and important issues: some simply assume that the problem is not there; others argue that the problem of revisionism is so prevalent that we are better off studying the status quo. We 
are, crudely speaking, dealing with Defensive Realists who assume that all states are status quo players (Waltz, 1979), and Offensive Realists who assume that all states are revisionists (Mearsheimer, 2001). These Realist perspectives essentially fail to elaborate on the sources of change, which were examined by Classical Realism, and which must be investigated if we are to understand the durability of the Western principles that won the Cold War and also the way in which powerful actors are likely to contest these principles. In short, Classical Realism contains conceptual tools that make it the most promising member of the Realist family. In this article, we outline how Realists should go about using these tools to understand change, and we identify questions that can inspire future Realist research on revisionism and the status quo.

We are in several ways suggesting that Realism must return to its roots. Classical Realism was premised on the belief that one must understand world politics qua the ambitions of the states inhabiting this realm. Classical Realism was thus international relations and foreign policy analysis integrated. Subsequently, and ultimately to the detriment of political understanding, we argue, Realists retreated into structural conceptions of world politics while their critics occupied the field of foreign policy analysis. Structural Realists would thus argue that all states are pushed to do certain things (though they disagree whether the push is defensive or offensive) while foreign policy analysts would argue that policy should be understood primarily as the outcome of bureaucratic politics and cognitive processes. The stage was thus set for an often acrimonious debate between Realists operating on the outside of states and a motley crew of Realist critics operating on its inside.

Some Realists have in the 1990s begun to move beyond this debate and seek to re-integrate international relations and foreign policy-making in their understanding of world politics. Neoclassical Realists, these people are often called, although we shall argue that Neoclassical Realists represent one of two pillars in the new and reconstructed house of Classical Realism. This house is founded on the assumption that liberalism does not represent the finalite of political aspiration (see Fukuyama, 1993), that different actors harbour different and sometimes conflicting ambitions, and that we must inquire into non-Western ways of thinking - the cultural infrastructure of nations and regions that now gain opportunities to assert themselves - to understand the nature and impact of revisionism.

Classical Realism is thus a particularly appropriate platform from which to engage in the debate on global change - a debate marked by grand questions and contending perspectives. Observers can agree that strategic relations are increasingly complex and marked by cultural and political plurality, but some observers infer from this that statesmen should refrain from games of deterrence due to the growing risk of accidental war based on inflated and erroneous beliefs (Lebow and Stein, 1989; Mercer, 1996); other observers infer 
that new strategies must be based on offensive and sometimes pre-emptive action (Krauthammer, 2002). Yet other observers emphasize the cultural and political dimension and argue that the West, steeped in Clausewitz's thinking, simply does not understand its adversaries and their indirect strategies (Van Creveld, 1991; Keegan, 1993; Arreguín-Toft, 2005). Still others find an inability to coexist across civilizational boundaries and predict clashes along these boundaries (Huntington, 1998). These questions all emerge from a concern with revisionism in one form or another, and it would be timely if Realists generally began delving into the 'purposive or meaningful action' that should be part of all assessments of power politics (cf. Carr, 1991, 86).

The article is divided into three sections. It begins with an overview of Classical Realism, its roots and main contributions. It also outlines the criticisms raised against Classical Realism, which spurred the development of modern Realism and the attempt to theorize the structure of the international system and the way in which it pushes states to adopt certain policies. The second section of the paper reviews modern Realism with regard to revisionism and international change. The final section defines a new research agenda. Classical Realism is particularly appropriate as a framework for analyzing current world politics, we argue, but to do so it must face its critics. This leads us to set up three pathways of inquiry and deduct key questions for future research.

\section{Classical Realism}

Classical Realism's most important roots arguably date back to the fall of the medieval Roman Catholic realm. Medieval Europe entertained the same myth of universalism as its competitors, the Byzantine Empire and the Islamic caliphates, but it never enjoyed the same ability to pursue it in practice (see Bozeman, 1994). Gradually, therefore, universalism gave way to particularism, and scholars and observers promoted the shift by developing new doctrines of state interest (raison d'état) and balances of power (Vagts, 1948; Haslam, 2002, chap. 1 and 2). In the early 20th century, scholars of the interwar generation picked up these concepts and insights and gave birth to the tradition of Classical Realism as a coherent body of thought. It was coherent in the sense that it was clearly delimited from its intellectual competitors, notably liberal thought in the shape of Idealism. It was less coherent on other issues, however, and this became a primary source of the onslaught on Classical Realism, also within the Realist tradition of thinking. We begin with an overview of the interwar generation before proceeding to problems and challengers.

Prominent scholars of the interwar generation include Reinhold Niebuhr, Edward H. Carr, Georg Schwarzenberger, and Nicolas Spykman, and they 
would go on to inspire people like Hans Morgenthau, Raymond Aron, Stanley Hoffmann, Arnold Wolfers, George Kennan, Henry Kissinger, and others. Classical Realists share an understanding of social reality as collective, which is to say that the group is the essence of social reality, and of politics as a contentious struggle among these groups over values (see Gilpin, 1986). Thus, harmony is utopia. A semblance of harmony may be imposed but it is just that - imposed and thus representative of a certain type of order which inevitable engenders opposition and revolt.

Political conflict is rooted in human affairs and more particularly human nature, according to Classical Realists. Reinhold Niebuhr believed that humans had a potential for 'evil', and with human kind's increasing grasp of science and control of society, the scope for human evil expanded. Social groups - such as nations and states - may contain many ethical people but the glue of these groups - 'patriotism' - contains a 'paradox': it 'transmutes individual unselfishness into national egoism' (Niebuhr, 1932, 91). Hans Morgenthau sought to provide 'a theory of international politics' focused on the 'objective laws' of politics and rooted in 'human nature' (Morgenthau, 1993, 3-4). Morgenthau may have been less preoccupied by the 'evil' nature of man compared to Niebuhr but he maintained that the desire for power was universal (Waltz, 1959, 34).

Niebuhr and Morgenthau thus created inextricable links between individuals and collectivities, partly because individuals live in groups (i.e., the essence of social reality), partly because groups' occasional warring is rooted in human nature. By implication, Classical Realism does not distinguish between the 'first' (the individual) and 'second' (the state) image in the assessment of why tragedy happens. Kenneth Waltz nevertheless built his criticism of prevailing international theories, thus including Classical Realism, on the notion of distinct images, and he associated Classical Realism with the first image (human nature) (Waltz, 1959). The distinction is valid insofar as Classical Realists find that revisionist states - those wrecking havoc in international politics - somehow emerge from human nature. But the distinction also obscures the care with which they connected these two images or levels. Hans Morgenthau, for instance, underscored that 'national character and national morale' have a 'permanent and often decisive influence upon the weight a nation is able to put into the scales of international politics' (1993, 143). A similar focus is found in Stanley Hoffmann's treatment of the 'national situation' - a composite measure of objective and subjective factors - that 'any statesman' must take into account $(1974,368)$. The point is that for Classical Realists, the phenomenon of revisionism will always appear in particular political-historical contexts and that little real understanding is gained by referring conflicts merely to an abstract idea of evil. 
This link between the first and second image invites further thought on the distinction between individual and collective morality. Edward H. Carr explored this issue in depth. His concern with morality sprung partly from his scathing realist criticism of utopias in various guises, partly from his acute understanding of the 'limitations of realism', which is to say, his awareness that values and visions - indeed, all kinds of purposes - must be allowed a place in political thought if we are not to destroy it $(1991,91)$. It is true, Carr argued, that 'there is a world community' (although mainly because we continue to imagine that it is there) which can inspire the idea of a global moral codex $(1991,162)$. It is equally true, however, that the principle of equality is not applied in practice and moreover is not generally accepted. Still, morality and power are not mutually exclusive, Carr argued in his 'limitations of realism' vein. 'Those who profit most by [an] order can in the long run only hope to maintain it by making sufficient concessions to make it tolerable to those who profit by it least; and the responsibility for seeing that these changes take place as far as possible in an orderly way rests as much on the defenders as on the challengers' (1991, 169, italics added). For contemporary versions of this argument, see Lebow (2003) and Lieven and Hulsman (2006). From this responsibility flows a certain idea of international morality, albeit a distinctively realist one: order is based on power but power's purpose is partly to perpetuate order.

These subtle and pragmatic understandings of revisionism and morality informed Classical Realist assessments of world politics. Objective/ material power matters, Classical Realists argue, but so does subjective/ political power: politics will define morality's corruption and revisionism's vigour. Analysis operating at the international level only (i.e., Neo-realism) is faulty by design: any coherent analysis must combine an understanding of the international with that of the domestic. This approach informed Arnold Wolfers' contention that an 'objective national interest' cannot be defined: national interests are political and therefore subjective (Wolfers, 1962). It also informed Raymond Aron's depiction of 'heterogeneous' and 'homogenous' international systems based on the foreign policy goals of major powers $(1984,108)$. Likewise, it informed Henry Kissinger's claim that international stability does not result from quests for peace but from legitimacy $(2000,1)$, and also A.F.K. Organski's argument that the greatest wars result from situations where a new power gains parity with the reigning status quo power and in addition is dissatisfied with the existing order (1968).

Classical Realism faded following a golden age approximately coinciding with the 1950s. The reasons for this decline are many and complex, but three key criticisms should be mentioned. 
- Classical Realism as self-destructive nihilism. This criticism relates to Classical Realism's refusal to provide an objective benchmark for international politics - because a proclaimed 'good' is always the good of particular groups - and a subsequent inability to distinguish between power's legitimate and illegitimate use. Some Classical Realists were sympathetic toward the wretched of this Earth (the Marxist label was applied to both Niebuhr and Carr) and E.H. Carr drew particular criticism due to his sympathies for the Soviet Union - he allegedly overlooked the brutality of the regime - as well as his failure to condemn Hitler in the 1930s. Carr also failed to gain the sympathy of small states when he went against the principle of self-determination. ${ }^{2}$ Morgenthau did oppose the Vietnam War but this moral stance came at a moment when, allegedly, he, along with Niebuhr, 'committed a form of intellectual suicide' by moving outside the Realist realm, impressed as they were by destructive potential of the thermonuclear age (Craig, 2003, 116).

- Classical Realism as slippery and inconsistent theory. This line of criticism relates to how Classical Realists typically enumerate such foreign policy goals as Power, Security, and Glory (Aron, 1984) - the terms differ slightly - and then go on to assess constellations of them. The problem, critics contend, is that Realists argue that all states are entangled in the perennial struggle for more power while they also contend that these states pursue different goals - some are revisionist, others are status quo oriented. The explanatory tools of Realism do not tell us when and why policy goal variation is likely to happen: both anarchy and human nature are constants that do not explain variation (Donnelly, 2000, 64). This built-in flexibility, or perhaps ambiguity, is, the critics contend, a severe problem for theory-building, generally speaking, and Classical Realists were therefore led to understand policy via intuition - a slippery slope.

- Classical Realism as misguided theory. Classical Realists, as we saw, account for war by pointing to the intricate links between human nature and political units. Kenneth Waltz's Neo-realism moves the focus to the third image or level - the structure of the system. Anarchy is the enduring 'permissive or underlying cause of war' while people and states account for particular wars (1959, 232). Later, in his Theory of International Politics, Waltz pressed his structural point by stating that 'In order to take Morgenthau, Kissinger, Levy and the rest seriously, we would have to believe that no important causes intervene between the aims and actions of states and the results their actions produce' (1979). As the title of his 1979 book indicates, Waltz engaged Morgenthau's theoretical ambition - to provide 'a theory of international politics' - and saw in it a gateway for criticizing the collective body of Classical Realism. 
These criticisms combined to cause the disintegration of Classical Realism. Realism continued but now under the leadership of the Neo-realist Kenneth Waltz, and the debate between Neo-realists and their critics focused on the definition and impact of anarchy. In the following section, we demonstrate that the foretold death of Classical Realism was wishful thinking.

\section{Modern Realism: Combining Levels of Analysis}

Realists never ceased to study revisionist states, it should be understood. The problem is not one of focus but one of treatment: new Realists subsume revisionism under structure and treat it either as an anomaly or orthodoxy. Neither approach is very fruitful. Defensive realists assume that states tend to behave as 'defensive positionalists' or satisfied status quo powers (Grieco, 1993, 303; Schweller, 1996, 101): thus, revisionist states become anomalies requiring explanation. Offensive realists head in the other direction, claiming that the international system is so dangerous that revisionism is orthodox policy. The middle ground in this debate is claimed by the children of Classical Realism, which treats the status quo-revisionist distinction as an independent variable. We briefly review each of these three positions.

\section{Defensive Realism and the irrational, malicious state}

In the Defensive Realist world, states are prudent and survival is best assured through moderation and restraint. These predictions follow from Defensive Realism's two core assumptions: 'That the order be anarchic and that it be populated by units wishing to survive' (Waltz, 1979, 121). States are like units: even though they have different levels of national power, they all pursue the same defensive goal. 'In anarchy, security is the highest end. Only if survival is assured can states seek such other goals as tranquillity, profit, and power... The first concern of states is not to maximize power but to maintain their positions in the system' (Waltz, 1979, 126).

How can these cautious security-maximizers survive anarchy? Partly by balancing power but also notably by exploiting the defensive potential of the offensive-defensive balance in military affairs. Defensive Realists argue that defensive military measures often outperform offensive weapons and strategies. ${ }^{3}$ Consequently, Defensive Realism posits that states have no real incentives to become revisionist and the expansionist state is the rare exemption in defensive realism. ${ }^{4}$ 'In its current stress on maximizing security and avoiding relative losses, contemporary realism [Defensive Realism, SR \& JR] view the world through the lens of a satisfied, status quo state' (Schweller, 1996, 101; also Schweller, 1994). 
If the international system provides no rational explanation for revisionist behaviour, then how do Defensive Realists account for actual attempts at expansion? At this point, Defensive Realism needs to bring in domestic-level variables. Zakaria writes:

In practice, of course, states often try to expand beyond these objective security requirements, but defensive realism refuses to attribute any of this expansion to systemic incentives. The international system pressures states towards moderate behavior only, anything else must be explained at some other level of analysis because it cannot be a rational response to the international environment. (Zakaria, 1992, 192)

To the Defensive Realist, therefore, expansionist powers are anomalies calling for auxiliary assumptions and hypotheses related to first and second image variables (Rose, 1998, 150; Rynning and Guzzini, 2001). Jack Snyder (1991) thus analyzes how great power overexpansion stems from 'cartelized' political systems, where 'power assets... are concentrated in the hands of parochial groups, each with very narrow interests' (Snyder, 1991, 31) — and each capable of engaging their state in unwanted, dangerous foreign policy adventures. Similar arguments are found in Charles Kupchan (1994), Barry Posen (1984), and Stephen Van Evera (1990/1991). ${ }^{5}$ In sum, Defensive Realism depicts a 'world of all cops and no robbers' (Schweller, 1996, 91). When robbers do appear, it is because some states are pathological, and the causes of malady are found beneath the systemic level.

\section{Offensive Realism: Revisionism, Business as Usual}

Offensive Realism is the mirror-image of Defensive Realism. The two Realisms are based on the same core assumption. ${ }^{6}$ Like Waltz and his followers, Offensive Realists assume that states are mainly concerned 'with figuring out how to survive in a world where there is no agency to protect them from each other' (Mearsheimer, 2001, 21). However, where Defensive Realists contend that the international system provides few incentives to expand, their offensive counterparts maintain that anarchy often encourages self-extension. ${ }^{7}$ Defensive Realists' view of international anarchy is often benign, akin to Rousseau's state of nature, whereas Offensive Realists' see a belligerent world akin to Hobbes' raw anarchy.

Offensive Realists therefore argue that the best strategy towards survival is not to preserve but to increase power (Snyder, 2002). States should thus be expected to be revisionist, and the exception is the rare hegemon. States are not assumed to be mindless aggressors, it should be noted: the point is that aggression more often than not has been successful. 
There is no question that systemic factors constrain aggression, especially balancing by threatened states. But defensive realists exaggerate those restraining forces. Indeed, the historical record provides little support for their claim that offense rarely succeeds. One study estimates that there were 63 wars between 1815 and 1980, and the initiator won 39 times, which translates into about a 60 percent success rate. (Mearsheimer, 2001, 39)

Strategies of revisionism are rational, as a rule of thumb. A power that leaves unexploited an opportunity for expansion is thus an anomaly (Snyder, 2002, 158; Zakaria, 1998, 29). This is then the point at which Offensive Realists are compelled to bring in domestic, state-level variables: Fareed Zakaria's study of US expansion $1865-1908$ is illustrative. ${ }^{8}$ The puzzling question to Zakaria is: the US had economic strength and awe-inspiring relative power for much of its history, but why did it not expand more and sooner? The explanation is found at the unit level where the state ultimately must wrestle resources from society and gain a free hand to allocate them to foreign policy (Zakaria, 1998, 35). The unit level thus serves the same purpose for Offensive and Defensive Realists: it explains pathological behaviour, although from distinctly different perspectives.

\section{Classical Realism: State-Motivation as a Unit-Level Variable}

As opposed to both Offensive and Defensive Realism, Classical Realistinspired foreign policy analysis is based on the assumption that states differ with regard not only to their relative power but also their primary motivations. A priori assumptions about 'objective' or 'rational' state interests are discarded. ${ }^{9}$ Survival is merely one out of several possible state interests that may result in a strategy of either revisionism or the status quo. In the words of Schweller: 'While I agree with the basic thrust of Zakaria's argument [that Defensive Realists tend to treat all states as defensive], I would not replace the defensive realist assumption with an influence-maximizing one as he suggests. Why choose one or the other?' (Schweller, 1998, 24n37; see also SterlingFolker, 2002) (Table 1).

By categorizing states according to their preferences, Classical Realism conspicuously distinguishes itself: Classical Realist do not only resort to unitlevel attributes when apparent anomalies require explanation, but explicitly include intervening first and second image variables into their theoretical foreign policy explanations. States by definition differ along two dimensions: power and interest (Rynning and Guzzini, 2001).

This renewed focus on Classical Realist insights has given birth to a new Realist off-spring, Neoclassical Realism. ${ }^{10}$ The main distinguishing feature of Neoclassical Realism is its emphasis on how systemic-level variables are 'translated through unit-level intervening variables such as decision-makers' 
Table 1 Typology of state interests in contemporary realism

\begin{tabular}{llll}
\hline & $\begin{array}{l}\text { Primary state } \\
\text { objective }\end{array}$ & Systemic pressure & $\begin{array}{l}\text { Rational state } \\
\text { preference }\end{array}$ \\
\hline $\begin{array}{l}\text { Defensive realism } \\
\text { Offensive realism }\end{array}$ & $\begin{array}{l}\text { Survival } \\
\text { Survival }\end{array}$ & $\begin{array}{l}\text { Defensive } \\
\text { Offensive }\end{array}$ & $\begin{array}{l}\text { Status quo } \\
\text { Revisionism } \\
\text { (hegemons excepted) }\end{array}$ \\
Classical realism & $\begin{array}{l}\text { Varies: e.g., security, } \\
\text { power, or glory }\end{array}$ & $\begin{array}{l}\text { Defensive or } \\
\text { offensive }\end{array}$ & $\begin{array}{l}\text { Status quo or } \\
\text { revisionism }\end{array}$ \\
\hline
\end{tabular}

perceptions and domestic state structure' (Rose, 1998; Wivel, 2005). Randall Schweller, the Neoclassical Realist who has most explicitly reintroduced state interests as a variable between structure and behaviour - or: power and policy - employs the concept in an attempt to construct a theory, which he labels 'balance of interests'. ${ }^{11}$ Schweller's main contention is that patterns of alignment and alliances predominantly are shaped by conflicting state motives: Status quo states will band with other defenders of the existing order, and vice versa. Compatibility of political goals is perceived as 'the most important determinant of alignment decisions' (Schweller, 1998, 22). Alliances must thus be understood as expressions of both power and purpose, which is how Sten Rynning accounts for NATO's enduring relevance (Rynning, 2005). Rynning has also accounted for change and continuity in French military doctrine since 1958 by demonstrating how domestic conditions can 'delay and shape the rational adaptation of doctrine to power incentives' (Rynning, 2002, 2). Likewise, Jason W. Davidson - partly building on the work of power transition theorists (e.g. A.F.K. Organski and Jacek Kugler) - analyzes how revisionist state objectives and their origins are crucial to the understanding of actual attempts to overthrow the reigning order (Davidson, 2002). Finally, Christopher Layne links NATO's durability to American domestic politics: he argues that the distribution of power in America's favor combined with an 'Open Door' outlook firmly entrenched in Washington explain 'America's drive for extraregional hegemony' $(2006,8)$.

Classical Realists grant state preferences a distinct role in their foreign policy analyses, thus prescribing a course between the Scylla of security-maximization and the Charybdis of power-expansion. The focus on varying state objectives is both tempting and problematic, however. It is tempting because it is likely to generate a more 'realistic Realism' that is comprehensive and attuned to real political conditions. It is problematic because it invokes the problems of the past, namely the charge that Classical Realism is both slippery and misguided. Naturally, these problems do not come as a surprise. Davidson (2002) counters the charge of slippery theory by building a theory of revisionism. Others argue 
that parsimony (i.e., structural theory) can and should be sacrificed in the name of explanatory power (Schweller, 1998, 10; Zakaria, 1998, 37; Rynning, 2002, 5). This brings us to the point at which we need to assess the general debate between modern-day Classical Realists and their critics.

\section{A Classical Realist Research Agenda}

The case for Classical Realism can be made on several accounts, which is what we will do. A promising place to begin is the current state of world affairs: it appears obvious in this context that Structural Realism — whether in its offensive or defensive guise - is risky business and that Classical Realism is the most appropriate framework of inquiry for our time. Why is this so? Essentially because the power constellations of the new world are uncertain and it would be capricious to prescribe policy without first investigating what it is that the new powers might want from their international engagements. The powers are partly non-Western - China, Russia, Japan, and India are all potential great powers in a not-so-far distant multi-polar world order (Calleo, 2004). The powers could also include a Western European component because the American vision of unipolarity tends to rub against the Western European vision of pluralism, if not multi-polarity. Classical Realists believe the moment of unipolarity is coming to an end and that we must prepare for it by studying politics. ${ }^{12}$ However, in order to reclaim lost territory, Classical Realism must face its critics, Realists as well as non-Realists, and demonstrate an ability to counter them while asking questions that are likely to generate new insights and, perhaps, wise policy. To outline these questions we return to the three sets of criticisms raised earlier in this article.

\section{International Morality}

Some critics claim that Classical Realism is nihilist and thus unable to distinguish between good and bad exercises of power. The critics typically go on to argue that we must replace Classical Realism with normative theory, the virtue of which is its point of departure - a coherent set of norms and values - which is then applied to politics in order to illuminate points at which changes ought to be introduced. Classical Realism is of course a prime case of normative theory because it focuses on the norms inherent in politics. Most critics know this, although some critics, such as Jack Donnelly, go on to argue that as normative theory it is 'an incoherent mess' $(2000,167) .{ }^{13}$ The problem seems to be that Classical Realism did not provide one overarching normative ideal but pointed out the way in which different actors embrace different ideals. 
How big a problem is this charge? An easy answer is to point out that if the theory is a normative mess, then it is because the world is a mess. But that would still leave the charge that Classical Realists simply lack the foundation for condemning regimes like Hitler's. The core of the charge is thus related to foundations and the need for a normative 'place to stand' if we are to move the world. ${ }^{14}$ One such place to stand could be liberalism and the doctrine of human rights: since we are all human beings, one way of distinguishing between good and bad politics might be to distinguish between regimes that respect or violate these rights.

However, this merely brings us back to the Realist critique of absolute standards and their tendency to degenerate into ideological crusades. Morgenthau wrote of the chasm between rational theory (such as liberalism) and political forces that are indifferent or hostile to reason: if we do not recognize this chasm and chart a prudent political course of action, we will end up with 'perfectionist' manifestations of rationalism (Morgenthau in particularly focused on Wilsonianism) that - disastrously — will seek to make reality conform to 'ethical commands' (Morgenthau, 1945, 3; 1946). The Classical Realist position is therefore that rather than using liberalism as a dogma, we should assess how liberalism as a political vision can be made possible in a world of conflicting, and sometimes clashing, visions.

Michael Williams believes that Classical Realism at its core focuses on the construction of social and political order, and he advocates a particular new brand — 'wilful realism' - that can be integrated with the constructivist research agenda $(2005,10-11)$. Williams' agenda is stimulating and dovetails with our agenda in this article, although we would hesitate to move the Realist project too far down the path of social constructivism. We do endorse, though, and indeed advocate the return to the Realist 'tradition.' Classical Realism should above all be classical, which is to say that it should analyze the meeting of mind and matter - subjective and objective factors - where constructivists privilege mind over matter.

Classical Realism should match power and principle in the assessment of international morality. Principles emerge from the 'national situation' of Stanley Hoffmann, and power is important to understand how a world order can be constructed. After all, as Carr argued, it is the responsibility of powerful states to satisfy other states - and thus counter the likelihood of revisionism. In the dialogue with other schools of thought Classical Realism should ask questions that advance its particular understanding of international morality and how revisionism relates to it. The starting point must be the interrelatedness of 'expediency and ideology' - a recognition of the difficulty of determining the point at which 'the recognition of national interest ends and obedience to moral principle begins' (Bozeman, 1994, 47 and 51). Questions for further research are then: 
- How do the major powers of the world today understand issues such as unity, peace, and law?

- Do major powers display a sense of responsibility toward the strength of international morality? Are they cognizant of the way in which 'accepted morality' can bolster the hegemony of great powers, and conversely the way in which immoral behavior can undermine these powers (Lebow, 2003, 361)?

- At what points are contemporary great powers in agreement, and do these points suffice as a basis for the creation of concerted great power governance?

\section{Understanding Foreign Policy Goals}

Other critics claim that the many types of foreign policy motivations found in Classical Realist literature imply that they want to have their cake and eat it too: they apparently want to theorize world politics - that is, uncover its essence - but then back off and slip into ambiguity when confronted with the question of what states are likely to do. If the answer to the question of state motivation is, 'that depends', then a general theory is impossible to construct (Donnelly, 2000, 74). These critics are to the point but they are also targeting a particular vision of Classical Realism that no longer represents the tradition. At issue is Hans Morgenthau's ambition to 'present a theory of international politics' (1993, 3). Most Classical Realists did not share this scientific vocation, and most ended up arguing explicitly that the endeavour would be futile. Thus, Arnold Wolfers argued that the introduction of multiple national motivations would 'rob the theory of the determinate and predictive character that seemed to give the pure power hypothesis its peculiar value' (Wolfers, 1962, 86). Likewise, Raymond Aron reached the conclusion that 'there is no general theory of international relations comparable to the theory of economics' (1984, 102).

Most Classical Realists would at the time subscribe to Hedley Bull's characterization of the 'classical approach', which he outlined in opposition to the newer approach of scientific inquiry. The analytical ambition, Hedley Bull argued $(1966,361)$, is to investigate philosophy, history, and law in a 'scientifically imperfect process of perception and intuition', and if generated propositions are 'tentative and inconclusive', it is because the subject matter politics — is dynamic and, in essence, scientifically imperfect.

The challenge for modern Classical Realists is to move beyond 'intuition' or at least anchor their intuitive understandings of politics in explicit conceptual analyses that can form the basis of intellectual dialogue. Once an analyst has more than one concept in hand, and once he or she is able to describe the variation in these concepts, then it is of course possible to connect the concepts as variables in a greater theory. We believe this pathway is both futile and 
misguided when it comes to understanding foreign policy goals. It is first of all misguided because the Classical Realists were intending to understand particular instances of state motivation: they were not trying to generalize but to understand. It is probably also futile because state motivation refers to meaning, and meaning is difficult to theorize.

Our suggestion, which is certainly in line with the Classical Realist way of thinking but which may nevertheless be disputed by theoretically ambitious people, is to analyze state motivation with an updated 'classical approach'. It will be classical because it is attuned to the subject matter of politics, and it will be updated because it draws on Max Weber's method of ideal types (Weber, 1949). These ideal types are feats of imagination, combining interpretive and scientific conceptions of knowledge, which emphasize certain aspects of reality, and the purpose of using them, of matching ideals with reality, is to understand concrete instances or cases of reality. We are arguing, in line with the traditional Weberian logic recently advanced by Puchala $(2003,38)$, that both scientific and interpretive approaches can be legitimate but that they are not always equally useful. In the realm of foreign policy goals and state motivation we are dealing with particularities, unique phenomena that must be grasped interpretively. Still, and to avoid relying on mere intuition, Classical Realists should conceptualize the ways in which material interests and ideas combine in types - ideal types - of state motivation and use these for the purpose described by Weber as 'explanatory understanding' $(1978,8)$.

One place to begin might be Schweller's presentation of strong and weak revisionists as well as strong and weak status quo players. The further development of these images should draw on Stanley Hoffmann's concept of 'national situation', and it would be interesting to bring Classical Realism into dialogue with the constructivist researchers who have taken up Kalevi Holsti's concept of 'national role theory' (see Holsti (1970); for constructivist approaches see Chafetz et al., 1996; Aggestam, 1999). Classical Realism and role theory can share in the endeavour to construct role typologies but they should then explore their distinct potentials for furthering our understanding of why some states become revisionist. For Classical Realism, key questions are:

- Which aspects of the 'national situation' are particularly relevant to the creation of ideal typical foreign policy actors? Colin Gray (1999, 148-150) builds on 'seven non-exclusive categories' of factors comprising nationality, geography, service branches and weapons, simplicity-complexity, generational experience, and grand strategy: are these categories appropriate for all types of actors?

- A 'national situation' will only inform, not determine, foreign policy, and it may also contain several distinct 'strategic cultures'. What happens when 
states contain several strategic cultures? Are 'single' cultures typical for certain, or, conversely, all states?

- How do states with distinct role conceptions respond to power shifts? We know that revisionism will occur when dissatisfied states gain opportunities for action; but is it likely that revisionism also is the indirect product of the juxtaposition of certain types of states? For instance, that 'protectee' states look favorably on 'regional protector' hegemons but resist 'anti-imperialist' hegemons? ${ }^{15}$

\section{Explaining Policy and Conflict}

From within the tradition of Realism, critics have faulted Classical Realists for explaining systemic outcomes on the basis of national attributes. According to this criticism, Morgenthau, Kissinger, Aron and other Classical Realists attempted to understand the whole by its parts and thus became guilty of reductionism (Waltz, 1979, 60-78). Waltz and other Neorealist critics did not believe that war could adequately be explained by reference to revolutionary or revisionist states. We sometimes observe such states without war, they argue, and we must grasp the forces that operate at the systemic level.

This intra-Realist criticism is flawed for two reasons. Firstly, it is off the mark. Classical Realist did utilize first and second image explanations of foreign policy and international politics, but these images never became matters of 'exclusive attention' or 'central concern' — as Waltz otherwise argues $(1979,65)$ : relative power and systemic forces were always at the heart of Classical Realism. Secondly, Waltz is right in stating that the very existence of a troublemaker is not tantamount to trouble. But Waltz's argument that conflict spring from the security dilemma is no solution. As Randall Schweller argues, the concept of security dilemma is essentially rooted in the idea of revisionism: 'It is only the misplaced fear that others harbor aggressive designs that drives the security dilemma. In their reliance on the assumption of imperfect information to explain conflict and balancing behavior, neorealists (read: Waltz and his students) violate realism's most basic tenet that conflicts of interests among states are genuine rather than the result of misunderstandings and misperception' (Schweller, 1996, 118).

Classical Realists can combine understandings of revisionism and power in ways that Structural Realists cannot. This does not mean that modern Classical Realists agree on the line of inquiry, and we can in fact detect three distinct approaches to the study of revisionism and international change.

The first is the school labelled Neoclassical Realism. The purpose here is to understand foreign policy variation, for instance in relation to alliance choice 
or military doctrine. The framework of analysis consists of an independent variable (international power) and intervening variables (issues of domestic politics), and then the dependent variable (policy). Neoclassical Realism's theoretical ambition is thus different from the above (the up-dated classical approach) and is developed in the spirit of scientific inquiry. Still, it should be noted that Neoclassical Realists, like all Classical Realists, believe that the world is out there (and thus can be explained) but also that it changes (and thus that our explanations must change). Neoclassical Realists are therefore inclined to use case studies and to make limited causal claims.

The second approach is more theoretically ambitious and seeks to provide general explanations for phenomena such as revisionism. The approach stems from the criticism raised against Schweller who merely posits that states have varying goals and interests: allegedly, he 'slights discussion of the sources of revisionism and so fails to integrate the concept organically into his broader systemic argument' (Rose, 1998, 165). Davidson (2002) has taken up the challenge and believes that revisionism has general causes. Davidson would thus not approve of our above argument that roots of ambitions are best understood via an up-dated classical approach; in contrast, we are sceptical about the feasibility of Davidson's approach, and certainly about the insights it can generate into 'national situations'.

The final approach is systemic in the sense that it does not analyse policy but policies and the typical outcomes of their encounter. This is the approach adopted by Randall Schweller in his assessment of the causes of World War II, and which leads him to argue that he does not need to know why, for example, Germany was strongly revisionist; what matters is that it was, and that it occupied a prominent role in the European balance of power (1998). Thus, a Classical Realist assessment of revisionism and conflict would consider the interaction between the distribution of revisionism and the distribution of power.

The research agenda of each of these approaches should be pushed further:

- On Neoclassical foreign policy analysis: In what ways should we conceptualize international power (the independent variable)? In other words, do different states respond to different power challenges? And should we then conceptualize the policy process (intervening variables) differently, depending on the type of state?

- On the causes of revisionism: Is it at all possible to generate a theory of revisionism? Davidson argues that we must theorize revisionism's roots but can we meaningfully create a limited number of archetypical revisionisms and then connect these to a few, explanatory sources? And in theorizing the archetypes, what 'relative weight should be assigned to the two levels of causation' (Dray, 1980, 91)? 
- On the meeting of status quo and revisionisms: What are the most important meetings taking place (i.e., the most violent or most peaceful; and of which types of states are they composed)? Can we meaningfully compare these cases? What is the implication for current world politics?

\section{Conclusion}

For decades Classical Realism has been relegated to a humble position within the Realist research program, partly because Neorealists promised both parsimony and insight, partly because Neorealists and other critics argued that Classical Realism was altmodisch and a-theoretical. A central concern of world politics today is the likelihood that one or several powerful states will seek to revise the Western order, and we argue that the Classical Realist understanding of international politics must be revitalized to enable us to understand war and peace in our time. Classical Realism has the tools for grasping why some states develop revisionist foreign policies and seek to upset politics among nations. In this article, we have sought not only to identify the questions that can inspire research but also to underscore that epistemological and methodological strife should be placed in context: the choice of explanation or understanding must be made in relation to the question one asks. Classical Realists must now ask pertinent questions and provide meaningful answers. The research agenda of this article is one place to begin.

\section{Notes}

1 An earlier version of this article was presented at the 'EUROPA' workshop at the Department of Political Science, the University of Southern Denmark, 13 April 2005, as well as at the 'Foreign Policy Analysis: Theory and Practice' workshop at the ECPR conference in Granada, Spain, 14-19 April 2005. The authors are grateful to all participants for general comments and are particularly indebted to A.J.R. Groom, Georg Sørensen, and Robert H. Lieshout for their specific suggestions for improvements.

2 Concise and insightful discussions of Carr are found in Michael Cox $(2000,2001)$.

3 Key works emphasizing the offence-defence balance include Jervis (1978), Snyder (1991), Lynn-Jones (1995), Van Evera (1998, 1999), and Powell (1999).

4 According to Barry Posen, a Defensive Realist, status quo states are 'the rule rather than the exception' (Posen, 1984, 69).

5 Fareed Zakaria provides a trenchant critique of what he considers as Defensive Realisms exaggerated use of explanations rooted in domestic politics in 'Realism and Domestic Policy: A Review Essay' (1992). 'Neorealism is often loosely characterized as "leaving domestic politics out", but in fact defensive realism has the opposite tendency; it uses domestic politics to do all the work in its theory' $(1992,192)$. For a similar argument, see Rose (1998).

6 For a discussion of the usefulness of defensive and offensive auxiliary assumption, see Labs (1997).

7 Important examples of Offensive Realist work include John J. Mearsheimer (1990, 1994/95, 2001), Fareed Zakaria (1992, 1998), Eric J. Labs (1997), and Andrew Kydd (1997). 
8 Zakaria classify himself as a Classical realist. Sean Lynn-Jones, however, argues convincingly, that Zakaria's Realism is Offensive. Zakaria's 'arguments differ from classical realist claims that state behavior is shaped by the structure of the international system, but also by a lust for power that is inherent in human nature, and that revisionist and status quo powers have different motives and objectives' (Lynn-Jones, 1998, 162).

9 It is important to note that the Classical Realist distinction between revisionist and status quo states does not refer to actual state behaviour or foreign policy choices, but merely to the preferences over outcome. States pursuing revisionist objectives are often compelled to act as status quo states, simply because their relative power-potential is insufficient. 'Revisionist states are not always actively engaged in overturning the status quo; they may be temporarily passive because they lack the relative economic, military, and/or political capabilities needed to challenge the protector(s) of the status quo' (Schweller, 1998, 25). See also Jason Davidson (2002) and Barry Buzan (1991, 294-327).

10 Key members of the Neoclassical family include Randall Schweller, Jennifer Sterling-Folker, William C. Wohlforth, Daniel Byman and Kenneth Pollack. For an insightful discussion of the properties of Neoclassical Realism and a specification of the lines of demarcation between different Realist approaches to the study of foreign policy, see Rose (1998).

11 The work of Randall Schweller has - most likely due to his elaborated criticism of Defensive Realism - more than once been erroneously classified as Offensive Realism (e.g. Taliaferro, 2000; Snyder, 2002). If Offensive Realism is meant to denote a study that makes the a priori assumption that rational states will pursue a strategy of expansionism, then this classification is mistaken. In fact, Schweller faults Offensive Realists for focusing to narrowly on survival as the sole state motivation (Schweller, 1999). 'Balance of interest'-theory cannot be pigeonholed as either Offensive or Defensive realism. It is neither.

12 Waltz's argument that unipolarity is an enduring structure is based purely on an assessment of material power and in particular its distribution (Waltz, 2000).

13 If there is a Realist tradition that is at fault in the debate over morality, it is Structural Realism: in it we find 'no guide for evaluating let alone making international moral choices' (Jackson, 1996, 212).

14 A particular version of this charge would be the postmodernist one. Postmodernists claim that all theory is a type of power, and they criticize Realists (and others) for believing that theoretical inquiries can help distinguish between rival claims. Theory, in this interpretation, is power, and Realists do not study but help perpetuate power structures. There is not much room for dialogue here, as Robert Jackson once noted (1996, 216), 'I cannot see how the classical approach could possibly accommodate theories which explicitly repudiate the classical tradition itself'.

15 The terms are from Chafetz et al. $(1996,734)$.

\section{References}

Aggestam, L. (1999) 'Role Conceptions and the Politics of Identity in Foreign Policy', ARENA Working Paper, 8/1999.

Aron, R. (1984) Paix et guerre entre les nations, Paris: Calmann-Lévy.

Arreguín-Toft, I. (2005) How the Weak Win Wars: A Theory of Asymmetric Conflict, Cambridge: Cambridge University Press.

Bozeman, A. (1994) Politics and Culture in International History: From the Ancient Near East to the Opening of the Modern Age, New Brunswick: Transaction Publishers.

Bull, H. (1966) 'International Theory: The Case for a Classical Approach', World Politics 18: 361-377. 
Buzan, B. (1991) People, States \& Fears 2nd edn, Boulder, CO: Lynne Rienner Publisher.

Calleo, D.P. (2004) 'The Broken West', Survival 46(autumn): 29-38.

Carr, E.H. (1991) The Twenty Years' Crisis, 1919-1939, London: Macmillan.

Chafetz, G., Abramson, H. and Grillot, S. (1996) 'Role Theory and Foreign Policy: Belarussian and Ukrainian Compliance with the Nuclear Nonproliferation Regime', Political Psychology 17: $727-757$.

Cox, M. (2000) 'Introduction: E.H. Carr - A Critical Appraisal', in M. Cox (ed.) E. H. Carr: A Critical Appraisal, London: Palgrave.

Cox, M. (2001) 'Introduction', in E.H. Carr (ed.) The Twenty Years' Crisis, 1919-1939, Houndmills, Basingstoke: Palgrave.

Craig, C. (2003) Glimmer of a New Leviathan: Total War in the Realism of Niebuhr, Morgenthau, and Waltz, New York: Columbia University Press.

Davidson, J.W. (2002) 'The Roots of Revisionism: Fascist Italy, 1922-1939', Security Studies 11: $125-159$.

Donnelly, J. (2000) Realism and International Relations, Cambridge: Cambridge University Press.

Dray, W. (1980) Perspectives on History, London: Routledge \& Kegan Paul Ltd.

Fukuyama, F. (1993) The End of History and the Last Man, New York: Perennial Books.

Gilpin, R.G. (1986) 'The Richness of the Tradition of Political Realism', in R.O. Keohane (ed.) Neorealism and Its Critics, New York: Columbia University Press.

Gray, C. (1999) Modern Strategy, Oxford: Oxford University Press.

Grieco, J.M. (1993) 'Understanding the Problem of International Cooperation: The Limits of Neoliberal Institutionalism and the Future of Realist Theory', in D. Baldwin (ed.) Neorealism and Neoliberalism - The contemporary Debate, New York: Columbia University Press.

Haslam, J. (2002) No Virtue Like Necessity: Realist Thought in International Relations Since Machiavelli, New Haven: Yale University Press.

Hoffmann, S. (1974) Decline or Renewal? France since the 1930s, New York: Viking Press.

Holsti, K.J. (1970) 'National Role Conceptions in the Study of Foreign Policy', International Studies Quarterly 14: 233-309.

Huntington, S. (1998) The Clash of Civilization and the Remaking of World Order, New York: Simon and Schuster.

Jackson, R. (1996) 'Is there a Classical International Theory?', in S. Smith, K. Booth and M. Zalewski (eds.) International Theory: Positivism and Beyond, Cambridge: Cambridge University Press.

Jervis, R. (1978) 'Cooperation under the Security Delimma', World Politics 30: 167-214.

Keegan, J. (1993) A History of Warfare, New York: Vintage Books.

Kissinger, H. (2000) A World Restored: Metternich, Castlereagh and the Problems of Peace, 1812-1822, London: Phoenix Press.

Krauthammer, C. (2002) 'The Obsolescence of Deterrence', The Weekly Standard, December 9.

Kupchan, C.A. (1994) The Vulnerability of Empire, Ithaca: Cornell University Press.

Kydd, A. (1997) 'Sheep in Sheep's Clothing: Why Security Seekers Do Not Fight Each Other', Security Studies 7: 114-154.

Labs, E.J. (1997) 'Beyond Victory: Offensive Realism and Expansion of War Aims', Security Studies 6: 1-49.

Layne, C. (2006) The Peace of Illusions: American Grand Strategy from 1940 to the Present, Ithaca: Cornell University Press.

Lebow, R.N. (2003) The Tragic Vision of Politics: Ethics, Interests and Orders, Cambridge: Cambridge University Press.

Lebow, R.N. and Stein, J.G. (1989) 'Rational Deterrence Theory: I Think, Therefore I Deter', World Politics 41: 208-224. 
Lieven, A. and Hulsman, J. (2006) Ethical Realism: A Vision for America's Role in the World, New York: Pantheon Books.

Lynn-Jones, S.M. (1995) 'Offense-Defense Theory and Its Critics', Security Studies 4 (summer) 660-691.

Lynn-Jones, S.M. (1998) 'Realism and America’s Rise: A Review Essay', International Security 23: 157-182.

Mearsheimer, J.J. (1990) 'Back to the Future: Instability in Europe After the Cold War', International Security 15: 5-56.

Mearsheimer, J.J. (1994/95) 'The False Promise of International Institutions', International Security 19: 5-49.

Mearsheimer, J.J. (2001) The Tragedy of Great Power Politics, New York: Norton.

Mercer, J. (1996) Reputation and International Politics, Ithaca: Cornell University Press.

Morgenthau, H.J. (1945) 'The Evil of Politics and the Ethics of Evil', Ethics 56(1): 1-18.

Morgenthau, H.J. (1946) Scientific Man versus Power Politics, Chicago: Chicago University Press.

Morgenthau, H.J. (1993) Politics Among Nations: The Struggle for Power and Peace, Boston: McGraw Hill.

Niebuhr, R. (1932) Moral Man and Immoral Society, New York: Charles Scribner's Sons.

Organski, A.F.K. (1968) World Politics, New York: Knopf.

Posen, B. (1984) The Sources of Military Doctrine: France, Britain, and Germany between the World Wars, Ithaca: Cornell University Press.

Powell, R. (1999) In the Shadow of Power: States and Strategies in International Politics, New Jersey: Princeton, UP.

Puchala, D.J. (2003) Theory and History in International Relations, New York: Routledge.

Rose, G. (1998) 'Neoclassical Realism and Theories of Foreign Policy', World Politics 51: 144-172.

Rynning, S. (2002) Changing Military Doctrine. Presidents and Military Power in Fifth Republic France, 1958-2000, Westport, CO: Praeger.

Rynning, S. (2005) NATO Renewed: The Power and Purpose of Transatlantic Cooperation, New York: Palgrave.

Rynning, S. and Guzzini, S. (2001) 'Realism and Foreign Policy Analysis', Working Papers 42, Copenhagen Peace Research Institute.

Schweller, R. (1994) 'Bandwagoning for Profit: Bringing the Revisionist State Back In', International Security 19: 72-107.

Schweller, R. (1996) 'Neorealism's Status-Quo Bias: What Security Dilemma?' Security Studies 5: 90-121.

Schweller, R. (1998) Deadly Imbalances. Tripolarity and Hitler's Strategy of World Conquest, New York: Columbia University Press.

Schweller, R. (1999) 'From Wealth to Power: The Unusual Origins of America's World Role (Review)', American Political Science Review June: 497-499.

Snyder, J. (1991) Myths of Empire: Domestic Politics and International Ambition, Ithaca: Cornell University Press.

Snyder, G.H. (2002) 'Mearsheimer's World. Offensive Realism and the Struggle for Security. A Review Essay', International Security 27: 149-173.

Sterling-Folker, J. (2002) Theories of International Cooperation and the Primacy of Anarchy. Explaining US International Monetary Policy-Making After Bretton Woods, Albany: State University of New York Press.

Taliaferro, J.W. (2000/2001) 'Security Seeking Under Anarchy: Defensive Realism Reconsidered', International Security 25: 128-161.

Vagts, A. (1948) 'The Balance of Power: Growth of an Idea', World Politics 1: 82-101.

Van Creveld, M. (1991) The Transformation of War, New York: Free Press. 
Van Evera, S. (1990/91) 'Primed for Peace: Europe after the Cold War', International Security 15: $7-57$.

Van Evera, S. (1998) 'Offense, Defense, and the Causes of War', International Security 22: 5-43.

Van Evera, S. (1999) Causes of War: Structures of Power and the Roots of International Conflict, Ithaca: Cornell University Press.

Waltz, K.N. (1959) Man, the State and War: A Theoretical Analysis, New York: Columbia University Press.

Waltz, K.N (1979) Theory of International Politics, New York: McGraw-Hill.

Waltz, K.N. (2000) 'Structural Realism after the Cold War', International Security 25: 5-41.

Weber, M. (1949) The Methodology of the Social Sciences, New York: Free Press.

Weber, M. (1978) Economy and Society, Berkeley: University of California Press.

Williams, M. (2005) The Realist Tradition and the Limits of International Relations, Cambridge: Cambridge University Press.

Wivel, A. (2005) 'Explaining Why State X Made a Certain Move Last Tuesday: The Promise and Limitations of Realist Foreign Policy Analysis', Journal of International Relations and Development 8: 355-380.

Wolfers, A. (1962) Discord and Collaboration. Essays on International Politics, Baltimore: The John Hopkins Press.

Zakaria, F. (1992) 'Realism and Domestic Politics: A Review Essay', International Security 17: $177-198$.

Zakaria, F. (1998) From Wealth to Power. The Unusual Origins of America's World Role, Princeton: Princeton University Press. 